\title{
Women Entrepreneurship: A Big Motivation
}

\author{
Shruti Balhara \\ Research Scholar, Department of Management \\ Chaudhary Ranbir Singh University, Jind, Haryana \\ E-mail: sbalhara24@gmail.com
}

Dr. Ajmer Singh

Department of Management, Chaudhary Ranbir Singh University, Jind, Haryana

E-mail: singhajmer@rediffmail.com

Received: September 10, 2015 Accepted: September 29, 2015

doi:10.5296/ber.v5i2.8452ＵRL: http://dx.doi.org/10.5296/ber.v5i2.8452

\begin{abstract}
Women Entrepreneurship is gaining popularity in India and Entrepreneurship amongst Women has been a recent concern which started only after the 1970's with the introduction of Women in India. Women Entrepreneurship is an important part of social and economic development of country. Women Empowerment is must for a modern developed economy through Women Entrepreneurship. This paper focuses on Women Entrepreneurship - Various Problems encountered by Women while setting up a new venture, To Study the factors which Motivates the Women to start their own venture, To Study the role of Government in the growth of Women Entrepreneurship. This Study also suggested some Supportive Measures for the development of Women while pursuing their business.
\end{abstract}

Keywords: Women Entrepreneurship, Women Empowerment, Women Growth, Motivational Factors Etc.

\section{Introduction}

The word "Entrepreneurship" is a combination of two words where "Entree" means 'to enter' and "Prendre" means 'to take' and in general sense we can say that it is an act of reviewing an existing business or setting up a new business so as to take advantages from new opportunities. A person who starts the enterprise is known as Entrepreneur. Various Characteristics Requirements for Entrepreneurship includes Risk-Taking, Decision-Making, Introspection Process, Goal Oriented and Innovative. 
A recent topic which started only after the 1970's with the introduction of Women's in India is Women Entrepreneurship. Educated Women demand equal respect from their partners and they don't want to limit their lives in the four walls of the home. Women Entrepreneur may be known as the Women or a group of Women, who start, organize and operate a business enterprise. Women Entrepreneurs defined by Government of India as an enterprise owned and controlled by woman whose minimum financial interest of $51 \%$ of employment generated in the enterprise to Women. In terms of contribution to economic development Women Entrepreneurs are the key players in any developing country. Motivational factors which are affected the Women to become an Entrepreneur like Economic difficulties and Changing atmosphere, Family background and interest, Economic support and knowledge, Social freedom, Career prosperity, Name and fame. Women Entrepreneurship is an important part of social and economic development of a country. Now Women have realized their importance in the society and their participation in economic activities is also increasing. Women Empowerment is must for a modern developed economy through Women Entrepreneurship. For ensuring empowerment of Women, educational attainment and economic participation are the key constituents. Women Empowerment is the term which has come to occupy an important position globally over the years. Various governments and voluntary organizations or agencies carried out seminars, workshops and conferences to show the value of Women activities like arrangement of training for Women, technology development etc. Right approach for Women Empowerment in developing economy will be Entrepreneurship among Women which enhance their socio- economic status.

The Objective of this paper is firstly to evaluate the Motivational Factors like Creative thinking, Education and qualification, Occupation for Family, Role model to others, Support for family members and Growth for self development etc. which motivates the women's to become an Entrepreneur. Secondly to investigate the various Management problems faced by women's in setting up of Enterprises. Thirdly good efforts and supportive measures are suggested for the development and empowerment of women like Financial Support, Training Support and various schemes introduced by SIDBI for the development of women's. The Research Methodology of the Study is based on Secondary data which is to be collected from newspaper, journals, conferences, articles, websites and census surveys.

\subsection{Review of Related literature}

(Satpal, Rathee Rupa and Rajain Pallavi, 2014), title "Challenges faced by Women Entrepreneurs in the Present Technological Era" revealed from the study Problems and Prospects of Women Entrepreneurship in India. Advancement of Women Entrepreneurs has contributed in Indian Economy a lot especially in 1990's. Due to modern technology investment, acquiring highest point in market, employment opportunities for Women increases. This is all due to education and increased awareness.

(Vaidivu and Devi Priya, 2013), title "A Study on Problems of Women Entrepreneurs" found in their study various motivational factors that mostly affected Women's are Challenge, Money Need, Initiativeness, Family help, Independent.

(Behara and Niranjan, 2012), title "Rural Women Entrepreneurship in India" This case 
study is related to Andhra Pradesh for Motivational factors such as Economic Independence, Establishing their own Creative Idea, Establishing their Own Identity, Excellence ,Confidence, Developing risk taking ability and Equal Status in Society.

(Masood, 2011), title "Emergence of Women- Owned Businesses in India- An Insight" This study was conducted by Masood on problems/ difficulties which cause to Women Entrepreneur like Non-Availability of Finance, Family Problems and Restrictions, IT Explosion etc.

(Jesrajan and Gnanadhas, 2011) title" Factors motivating Women to become Entrepreneurs" revealed study in Tirunelvi district by primary data of 300 Women Entrepreneurs. This study confers that economic independence, market potential, family background, utilization of funds are major motivational factors.

(Sanchita, 2010) title" A Study of Management Problems of Women Entrepreneur in Haryana". This study was conducted in Haryana for SSI's. Various problems includes lack of confidence, problem of finance, working capital, socio-cultural barrier, production problems, inefficient marketing.

(Buddhapriya Sanghamitra, (2009) title "Work Family challenges and their impact on Carrier Decisions" founded from study that if greater opportunities are available for Women it will helpful in poverty reduction. They give importance to regions as they accounts average per country. Other reasons for less participation of Women is due to low level of education, lack of training, heavy duties, religious conditions etc.

(Raman and Jaya Singham, 2008) title"Motivational factors affecting Entrepreneurial Decisions". This case study was based on 225 Women Entrepreneurs which are traded in small and medium industries in Malaysia. This study include exploring inner talent and doing something creativity and innovativeness.

(Sharma Sheetal, 2006) title "Educated Women Empowered Women". She concluded that for creating a good nation, Women Empowerment is must. It leads to the development of good family, good society and good economy.

\subsection{Objectives and Research Methodology of Study}

1. To evaluate the factors that motivates the Women to become an Entrepreneur.

2. To find out the various management problems encountered by Women.

3. To suggest some supportive measures for Women Entrepreneurship.

\subsection{Factors which motivates the Women to becoming Entrepreneurs}

Now a day Women are found indulged in every line of businesses. Indian Women are becoming increasing visible and successful in all spheres. Knowledge, skill and adaptability in business are main factors for Women to emerge into business enterprises. Women Entrepreneur is a person which accepts challenging role for becoming economically independent and to meet her personal needs. An inner desire to do something positive is an inbuilt quality of Women Entrepreneurial which helps in contributing values in both social and family life. With the 


\section{Macrothink}

Business and Economic Research ISSN 2162-4860 2015, Vol. 5, No. 2

advancement in Media, Women are aware of their rights, traits and work situation. A new talent of Women Entrepreneurs is forming today and they are flourishing as garment manufacturers, exporters, designers, pg owners etc.

\section{Various factors are}

- Social status and personal identity

- Qualification and education

- Occupation for family

- Role models for others

- Help from government organization

- Better future for their children

- Independent decision making

- Support for family member

- Face new challenge and growth for self fulfilment

- Creative thinking

This diagram shows the factors that motivates the Women for becoming Entrepreneurs.

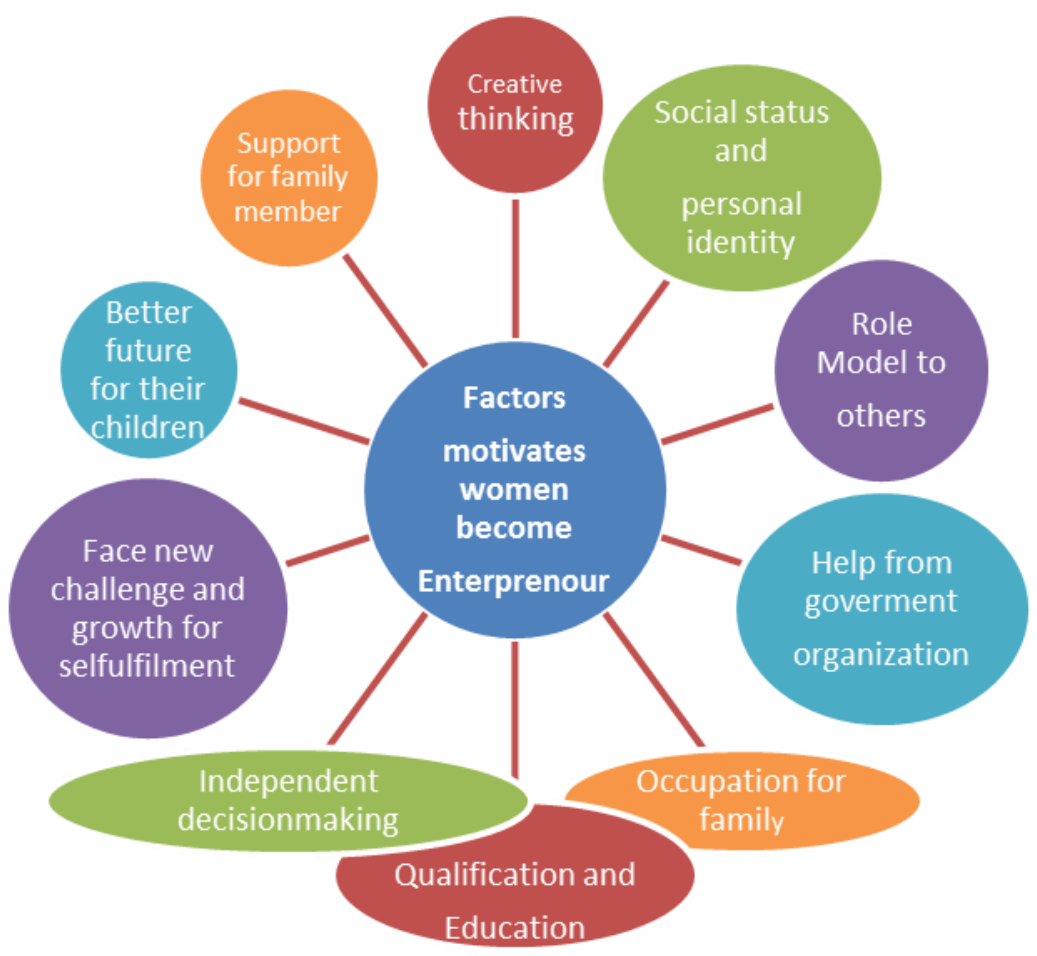

\section{Figure 1}

\subsection{Various Management Problems Encountered by Women}

1. Shortage of Finance: -Women Entrepreneurs are suffering from improper financial resources as Women don't possess any tangibles security in hand. 


\section{Macrothink}

2. Marketing problems: -Women Entrepreneurs face major problem in marketing their product and lot of money is needed to advertise their product. For advertising their product, Women's need middle men and they exploit the Women Entrepreneurs.

3. High competition: -Women Entrepreneurs have face tough competition from male Entrepreneurs having large experience. Women Enterprises have lack of knowledge about organisational setup.

4. High production cost: - High production cost of various operations badly affects the development of Women Entrepreneur's .It undermines the efficiency and stands in way of expansion and development of Women Entrepreneurs .Government assistance is provided to some extent which enables them to face over difficult situations.

5. Low risk taking ability:-Low level risk taking attitude is another factor which affects the Women to get into business. They face discrimination in selection of training development.

6. Lack of confidence:-Women lack confidence of their own abilities as Women are accepting a subordinate status.

7. Socio-cultural barriers: -Women have to perform various roles such as family, socio role in respective of her carrier as working woman. Many male members of family think that there is a big risk financing the business run by Women. Female-male competition is also another factor which creates problems to Women Entrepreneurs in the business process.

8. Lack of education: -Majority of the Women are still is illiterate in India. This is cause due to socio-economic problem. Women are not aware of technology, market knowledge and business due to lack of education and this cause low achievement motivation among Women.

9. Lack of training:-Large number of Women is suffering from lack of sufficient knowledge and professional training to setup a new business. So through EDPs training is given to all Women Entrepreneurs.

10. Family conflicts: - To look after the family members and their children is the main responsibility of Women in India. So a married Women Entrepreneur has to create a perfect balance between business activities and domestic activities. Without the proper support and guidance of husband Women Entrepreneurs can't succeed. Women also faces conflict of performing the home role as not available to spend time with their family as they spent long hours in business activities and difficult to meet the demand of family and conflict arises.

After establishing their business Women Entrepreneurs can experience some achievements like.

- Women can fulfil various financial requirement of their family and become financially strong.

- Women Entrepreneurs help in generation of employment of opportunities for other middle class Women.

\subsection{Supportive Measures for Women Entrepreneurship}

For development of women entrepreneurs, good efforts from all areas are required and more 
participation in the entrepreneurial activities. Various supportive measures are suggested to empower the Women are:-

1. Financial Support: - State Financial Corporation, District Industries Centres, Nationalised banks provide subsidies, loans and grants to women entrepreneurs. To overcome the financial problems in the way of setting up of enterprises. For setting up of new industrial projects by women entrepreneurs the scheme called Mahila Udyog Niti has introduced by Industrial Development Bank of India. NABARD provide refinance facilities and rendering assistance to women entrepreneurs.

2. Federations and its Associations Support: - Valuable efforts are making in the field of Entrepreneurship through federations and associations of Women. For promotion of women entrepreneurship, federation of societies of women entrepreneurship is engaged in various activities such as providing market assistance, involvement with government officials. At National level, association of women entrepreneurs are:-

- Indian Council for Women Entrepreneur (ICWE).

- Self- Employed Women's Association (SEWA).

- National Alliance of Young Entrepreneurs (NAYE).

3. Training Support for women entrepreneurs: - Training and award have been started for improving women entrepreneurship programmes. Especially for women entrepreneurs which are industrially backward and from rural areas, EDP has been conducted by Entrepreneurship Development, Ahmadabad. SBI started the 'Stree Shakti' package for women entrepreneurs who provide training facilities and concessions. Part time training facilities, mobile training centres should be offered to Women.

4. Educational Awareness: - To change the negative social attitude towards Women, educational and awareness programmers should be arranged so that to change the role of Women in society.

5. Marketing Cooperatives: - To sell the products on remunerative prices, marketing cooperatives will help the women entrepreneurs and helps in eliminating the middleman.

\section{Role of Government for Development of women entrepreneurs}

For promoting the women entrepreneur in India, various Governments, Non-Government, Promotional and Regulatory agencies play a supportive role. Employment generations programs, T\&D has also formulated by Government of India for women to start their new ventures.

- To develop the Entrepreneurial qualities among Rural Women "Prime Minister Rojgar Yojana" was introduced.

- A scheme called Women Cooperatives with full financial support from the Government was formed to help Women in agro based industry like horticulture, dairy farming etc. 
- To develop women entrepreneurs in rural, urban, semi- urban by developing qualities scheme called "Trade Related Entrepreneurship Assistance and Development (TREAD) scheme was launched by Ministry of Small Industries.

- To provide reservation for Women and to encouraging them to start their new ventures, Swarna Jayanti Swarozgar Yojana were introduced by Government.

- To help the women entrepreneurs SIDBI has introduced various schemes:-

$>$ MahilaVikas Niti: - It grants loan to Women to start their venture in field of knitting, weaving,spinning, handloom handicrafts etc.

Rashtriya Mahila Kosh: - It was set up to grant microcredit to poor women at reasonable rates of interest with simple procedures.

1.6 Various training schemes introduced by Government for self-employment of Woman are

- Small Industry Service Institutes

- National Small Industries Corporations

- District Industrial Centres

- Development of Women and Children in Rural Areas

\subsection{Conclusion of the Study}

On the basis of above discussion and suggestions it has been observed that women entrepreneurship has a bright or better future. Entrepreneurship Development among Women will be good approach for Women Empowerment. We have many Successful women entrepreneurs in our country as Women are good Entrepreneurs but we know that we have a male dominated society so various challenges are faced by Women from family. Various most influencing motivational factors for becoming the women entrepreneurs are :- Personal Identity, Occupation for Family, Role Model to Others, Independent decision-making, Better Future for their Children, Social Status, Creative thinking etc. It has been concluded from above discussion that Women faces many constraints when they start any new business but it is possible for a Woman to become a successful Entrepreneur when some help will be done by Government, Financial Institutions, Family etc.

\subsection{Various Efforts can be taken for Development of Women Entrepreneurs}

- Women Community should be provided with training programme on management skills.

- Women's participation in decision making should be encouraged.

- To understand the production process vocational training should be extended to Women Community.

- For procurement of raw materials, guidance should be provided to women entrepreneurs.

- For the display and sale of products by Women, marketing outlet could also be provided by Industrial Estates.

- Various programmes should be extended at local level for encouraging women Entrepreneurship. 
- To remove barriers like self-confidence, fear of failure, training and counselling to women entrepreneurs should be provided.

- To handle the problems of women entrepreneurs all over the state women entrepreneurs guidance cell has been set up.

- For small scale and large scale ventures, financial institutions should provide more working capital and assistance to women entrepreneurs.

\section{References}

Behara, S. R., \& Niranjan, K., (2012). Rural Women Entrepreneurship in India, International Journal of Computational Engineering \&Mgmt, 15(6), 6-15. https://www.google.co.in/?gfe_rd=cr\&ei=14HwVcX8NPTI8Aej4LbIBA\&gws_rd=ssl\#q=Rur $\mathrm{al}+$ Women+Entrepreneurship+in+India+by+Behara+and+Niranjan+volume+15

Buddha priya Sangha Mitra. (2009). Work Family challenges and their impact on Career Decisions: A study of Indian Women Professionals, Vikalpa, 34(1), PP.31-45. https://www.google.co.in/?gfe_rd=cr\&ei=14HwVcX8NPTI8Aej4LbIBA\&gws_rd=ssl\#q=\%E $2 \% 80 \% 9 \mathrm{CWork}+$ Family+challenges+and+their+impact+on+Carrier+Decisions+by+Buddhap riya+Sanghamitra+(2009

Goyal Meenu \& Jai Parkash, (2011). Women Enterpreneurship In India Problems and Prospects, International Journal of Multidisciplinary Research, 1(5), September 2011, ISSN 2231

https://www.google.co.in/search?q=4.+Goyal+Meenu+and+Jai+Parkash(2011)\%2C\%E2\%80 $\% 9 D W O M E N+E N T E R P R E N E U R S H I P+I N+I N D I A+P R O B L E M S+A N D+P R O S P E C T S \% E$ $2 \% 80 \% 9$ DInternational+Journal+of+Multidisciplinary+Research $\% 2 \mathrm{C}+\mathrm{Vol} .1+\mathrm{Issue}+5 \% 2 \mathrm{CSe}$ ptember+2011\%2C+ISSN+2231+-5780.\&oq=4.+Goyal+Meenu+and+Jai+Parkash(2011)\%2 C\%E2\%80\%9DWOMEN+ENTERPRENEURSHIP+IN+INDIA+PROBLEMS+AND+PROS PECTS\%E2\%80\%9DInternational+Journal+of+Multidisciplinary+Research\%2C+Vol.1+Issu e+5\%2CSeptember+2011\%2C+ISSN+2231+-5780.\&aqs=chrome..69i57.1476j0j8\&sourceid =chrome\&es_sm=93\&ie=UTF-8\#q=Women+Enterpreneurs+In+India+-+Emerging+Issues+ And+Challenges+by++3.\%09Dr.Vijay+Kumar\%2C+A.+and+Jayachitra\%2CS.\%09Dr.Vijay+ Kumar\%2C+A.+and+Jayachitra\%2CS

Huria Nitin. (2013). Women Empowerment through Entrepreneurship A way for Economic Development. International Global Research Analysis, 2(12), Dec.2013, ISSN NO 2277-8160. https://www.google.co.in/?gfe_rd=cr\&ei=6JLwVbCMAuzI8AfOs6_YDQ\&gws_rd=ssl\#q=W omen+Empowerment+through+Entrepreneurship+\%E2\%80\%9CA+way+for+Economic+De velopment $\% \mathrm{E} 2 \% 80 \% 9 \mathrm{D}+$ by+nitin+huria

Jesurajan, S. V., \& Gnanadhas, M. E. (2011). A Study on the Factor Motivating Women to become Entrepreneurs in Tirunelveli District, Asian Journal of Business and Economics, 1(1), $1-14$.

https://www.google.co.in/?gfe_rd=cr\&ei=14HwVcX8NPTI8Aej4LbIBA\&gws_rd=ssl\#q=Fac tors+motivating+Women+to+become+Entrepreneurs\%E2\%80\%9D+by+Jesrajan+and+Gnana dhas(2011) 
Kotler Philip, (2004). Marketing Management Pearson Education Publication Rani, Lalitha, D. (1996).Women Entrepreneur, A.P.H Publishing Corporation, New Delhi.

Mahajan Shikha. (2013). Women Entrepreneurship in India, Global Journal of Management and Business Studies, 3(10), (2013), 1143-1148, ISSN 2248-9878. https://www.google.co.in/?gfe_rd=cr\&ei=6JLwVbCMAuzI8AfOs6_YDQ\&gws_rd=ssl\#q=W omen+Entrepreneurship+in+India+by+shikha+mahajan

Panchal Rekha \& Dua Kavita, (2013). A Study on Motivational Factors for Becoming Women Entrepreneur In Haryana (India), International Monthly Referred Journal of Research In Management and Technology, Volume 11, June 13, ISSN-2320-0073 http://www.abhinavjournal.com/previous-issues-international.html

Raman, K., R. N, A., \& Jaya Singam, S., (2008). Motivational Factors affecting Entrepreneurial Decisions: A Comparison between Malaysian Women Entrepreneur and Women Non Entrepreneur, Communications of the Ibima, 2, 85-89. https://www.google.co.in/?gfe_rd=cr\&ei=14HwVcX8NPTI8Aej4LbIBA\&gws_rd=ssl\#q=Mo tivational+factors+affecting+Entrepreneurial+Decisions\%E2\%80\%9D.+by+Raman+and+Jay a+Singam(2008)

Rana. Zehra Masood, Researches world-journal of art science and commerce, 2(1), Jan.2011. https://www.google.co.in/?gfe_rd=cr\&ei=14HwVcX8NPTI8Aej4LbIBA\&gws_rd=ssl\#q=Pro blems+and+Issues+of+Women+Entrepreneurs+by+masood+2011

Sanchita. (2010). Small Scale Industries in Post Reform Era: A Study of Management Problems of Women Entrepreneur in Haryana, unpublished $\mathrm{PhD}$ thesis of Kurukshetra University,Kurukshetra.

https://www.google.co.in/?gfe_rd=cr\&ei=14HwVcX8NPTI8Aej4LbIBA\&gws_rd=ssl\#q=A+ Study+of+Management+Problems+of+Women+Entrepreneur+in+Haryana+by+Sanchita+(20 $10) \% 2 \mathrm{C}$

Sanchita. (2013). Women Entrepreneurship in Haryana: Challenges and Problems, Voice of $\begin{array}{lllll}\text { Research, 2(1), June 2013, ISSN } & \text { No. } & \text { 2277-7733. }\end{array}$ https://www.google.co.in/?gfe_rd=cr\&ei=R5TwVa6XDqXv8wfLnYGIAw\&gws_rd=ssl\#q=W omen+Entrepreneurship+in+Haryana:+Challenges+and+Problems+\%E2\%80\%9CVoice+of+ Research

Satpal, Rathee Rupa \& Rajain Pallavi. (2014). Challenges faced by Women Entrepreneurs in the Present Technological Era, International Journal of Advance Industrial Engineering, 2(2), (JUNE

2014). https://www.google.co.in/url?sa=t\&rct=j\&q=\&esrc=s\&source=web\&cd=1\&cad=rja\&uact=8 \&ved=0CB0QFjAAahUKEwiuo6D90urHAhVXkI4KHQYIBVs\&url=http\%3A\%2F\%2Finpr essco.com\%2Fwp-content\%2Fuploads\%2F2014\%2F07\%2FPaper254-57.pdf\&usg=AFQjCN HbtphYVgHXKFG10rzpXh0TJQ8kzA\&bvm=bv.102022582,d.c2E

Sharma Sheetal. (2006). Educated Women, Empowered Women, Yojana, 50(12), 52. https://www.google.co.in/?gfe_rd=cr\&ei=R5TwVa6XDqXv8wfLnYGIAw\&gws_rd=ssl\#q=E 


\section{Macrothink}

Business and Economic Research ISSN 2162-4860 2015, Vol. 5, No. 2

ducated+Women\%2C+Empowered+Women\%E2\%80\%9D\%2C+Yojana\%2C++by+sheetal+s harma

Websites

$\underline{\text { Www.shebusiness.com }}$

www.sciedu.ca/

https://en.wikipedia.org/wiki/Female_entrepreneur

http://www.businessfightspoverty.org/profiles/blogs/my-journey-as-a-woman-entrepreneur-i $\underline{\text { n-india-succeeding-with-some }}$

http://www.publishyourarticles.net/eng/articles2/eight-organizations-that-are-helping-womenentrepreneurs-in-india/2737/

\section{Copyright Disclaimer}

Copyright for this article is retained by the author(s), with first publication rights granted to the journal.

This is an open-access article distributed under the terms and conditions of the Creative Commons Attribution license (http://creativecommons.org/licenses/by/3.0/). 